\title{
The Performance Analysis of Private Conventional Banks: A Case Study of Bangladesh
}

\author{
Samina Haque \\ BRAC Business School, BRAC University, Bangladesh
}

\begin{abstract}
This study attempts primarily to measure the financial performance of some selected private commercial banks in Bangladesh for the period 2006-2011 and to identify whether any relationship exists between a bank's years of operation and its performance. For this purpose five banks have been selected from different generations. The financial performances of these banks have been scrutinized from the following four dimensions: (1) profitability (2) liquidity (3) credit risk and (4) efficiency. The study concluded that there is no specific relationship between the generation of banks and its performance. The performances of banks are dependent more on the management's ability in formulating strategic plans and the efficient implementation of its strategies. The study findings can be helpful for management of private commercial banks in Bangladesh to improve their financial performance and formulate policies that will improve their performance. The study also identified specific areas for each bank to work on which can ensure sustainable growth for these banks.
\end{abstract}

Keywords: Private commercial banks, performance analysis, financial ratios.

\section{Introduction}

The banking sector of Bangladesh is comparatively larger than many comparable economies with similar level of development and per capita income. The total size of the sector at present is $61 \%$ of GDP, which is proportionately large for a country with a per capita income of only about US\$870. [Source: Bangladesh Bank Quarterly Review, 2011]

The Banking sector of Bangladesh is divided into four categories of scheduled Banks. These are Nationalized Commercial Banks (NCBs), Government Owned Development Financial Institutions (DFIs), Private Commercial Banks (PCBs), and Foreign Commercial Banks (FCBs). Of them, the commercial banks are the most dominant one, accounting for more than $80 \%$ of all financial system assets. These commercial banks are subdivided based on ownership as state-owned commercial banks (SOCBs), private commercial banks (PCBs) and foreign commercial banks (FCBs). At present there are 43 commercial banks in Bangladesh, comprising 4 SOCBs, 30 PCBs and 9 FCBs.

The banking sector of Bangladesh is continuously growing with new banks coming in every now and then. Considering the year of establishment the banking sector of Bangladesh is classified in three generations.

Banks who have started its' operation from the period of 1971-1990 are classified as first generation banks. Banks incorporated from the period of 1991-2000 are classified as second generation banks. All banks getting license from 2000 till now are classified as third generation banks. As such this study has taken sample from all the three generations to get an overall idea about the financial performance of commercial banks of Bangladesh.

As discussed banking industry is a vital part of the financial system in Bangladesh. Thus, its successes or failure strongly affect the growth of the economy as well as its future prospect. In view of the above, a study of financial performance of banks in Bangladesh is useful to various interest groups such as the government, central bank and the community.

The study has been designed to measure the financial performance of some selected private commercial banks in Bangladesh through financial rations and trend analysis for the period 2006-2011. The selected banks have been evaluated from four dimensions: 1) Profitability, 2) Liquidity, 3) Credit Risk,4) Efficiency. The trend analysis has been undertaken to identify whether these banks are moving forward and how effectively these banks are coping up with the overall growth of other players in the industry. Moreover, the sample has been taken from different generations of banks to determine whether there exists any relationship between a bank's years of operation and its financial performance.

\section{Literature Review}

Different authors across the globe have measured financial performance of banks based on different techniques. Of which financial ratio analysis, trend analysis, CAMEL rating, are the most common tools used.

Almazari (2011) in his study measured the financial performance of some selected Jordanian commercial banks for the period 2005-2009. The study used simple regression analysis. In the study, bank size, asset management, and operational efficiency were taken as independent variable and dependent variable was 
taken as financial performance represented by; return on assets and interest income. The study concluded that banks with higher total deposits, credits, assets, and shareholders' equity does not always result in better profitability performance.

Ashraf and Rehman (2011) compared and analyzed performance of Islamic banking and conventional banking system in Pakistan by using of financial measures. The study analyzed the financial performance of selected banks from five different dimensions; i) Profitability, ii) Earnings, iii) Liquidity, iv) Credit risk and v) Asset activity for the period 2007-2010. The study concluded that the performance of Islamic Banks in Pakistan is lagging behind on the basis of performance because of increased operating cost and inefficiency from the part of management.

Kouser and Saba (2012) compared the performance of Pure Islamic banks, mixed banks and conventional banks in Pakistan using CAMEL rating. The study revealed the following facts i) Islamic banks have adequate capital and have strong asset quality compared to other banks in sample, ii) Islamic banks in general have more competent management compared to conventional banks, iii) the earnings of Islamic branches of conventional banks are greater than other banks.

Nimalathasan (2008) undertook a comparative study of financial performance of banking sector in Bangladesh using CAMELS rating system. The study was done on 6562 Branches of 48 Banks in Bangladesh for the financial year 1999-2006. The study revealed that out of 48 banks, 3 banks were rated 01 or Strong, 31 banks were rated 02 or satisfactory, 7 banks were rated 03 or Fair, 5 banks were rated 04 or Marginal and 2 banks obtained 05 or unsatisfactorily rating. 1 Nationalized Commercial Bank (NCB) had unsatisfactorily rating and other 3 NCBs had marginal rating.

Chowdhury (2002) in his study portrayed the state of banking industry of Bangladesh. In his study he emphasized that performance of banks requires knowledge about the profitability and the relationships between variables like market size, bank's risk and bank's market size with profitability. The study shed a light on the importance of performance evaluation of commercial banks in today's world. The study concluded that the banking industry in Bangladesh is experiencing major transition for the last two decades. The author recommended that the banks should endure the pressure arising from both internal and external factors and prove to be profitable.

Siddique and Islam (2001) undertook a study on commercial banks of Bangladesh for the financial year 1980-1995. The study revealed that the Commercial Banks, as a whole, are performing well and contributing to the economic development of the country. The average profitability of all Bangladeshi banks collectively was $0.09 \%$ during 1980 to 1995 . The study concluded that although banking sector contributes to the national economy as well as to the individual organization, the performances of different categories of banks were not equally attractive.

\section{Methodology}

To analyze the performance of Bangladeshi banks, the method of ratio analysis has been used. The ratio measure method is very simple and has been commonly used by many previous researchers. For example, Libby in 1975 and O'Cornor in 1973, Shimerda \& Chen in 1981, Sabi in 1996, Samad in 1999, Ahmed, Hassan in 2007, Ashraf and Rehman in 2011 used this method in their research work. The main advantage of this method is that it removes the disparities and makes the data more comparable. Five private commercial banks (National Bank Ltd., IFIC Bank Ltd., Dhaka Bank Ltd., Islami Bank of Bangladesh Ltd., and BRAC Bank Ltd.) have been considered for this research. The Financial Statements from 2006-2011 of all five banks were used for data analysis.

\subsection{Data Collection}

The data for this study have been gathered from secondary sources-the bank's financial statements for the year (2006-2011). These data have been used to compute key financial ratios of the selected commercial banks of Bangladesh for the mentioned period. This study has used a descriptive financial analysis to describe, measure, compare the financial performance of the selected commercial banks in Bangladesh.

\subsection{Sample Design}

For the study purpose five private commercial banks were chosen. Of them one was $1^{\text {st }}$ generation bank (AB Bank Ltd.), two were from $2^{\text {nd }}$ generation banks (Dhaka Bank Ltd. and Bank Asia) and two were from $3^{\text {rd }}$ generation banks (BRAC Bank Ltd. and Southeast Bank Ltd).

For the purpose of analysis, this study has used the major financial indicators comprised of total assets, total deposits, total credits, total shareholder equity, interest income. Under ratio analysis four dimensions have been used such as profitability, liquidity, credit risk and efficiency. Profitability dimension includes return on asset, return on equity, return on deposit, net profit margin, liquidity dimension includes cash ratio and loans to 
total deposit ratio, credit risk dimension includes equity to total asset and equity to net loans ratio and finally efficiency dimension includes fixed asset turnover and net asset turnover ratio.

\section{Results and Discussion}

Table 1 shows the total assets of all selected private commercial banks of Bangladesh for the year 2006-2011 and provides the growth rate of assets, taking 2006 as the base year. From the table it is clear that Southeast Bank had the highest acceleration in asset base, whereas Dhaka Bank encountered the lowest growth during these years. From the perspective of asset growth it can be said that both the selected $3^{\text {rd }}$ generation banks had the highest growth during the years under consideration.

Table 1: Total Assets of the Selected Bangladeshi Commercial Banks (2006-2011)

\begin{tabular}{|l|l|c|c|c|c|c|c|c|c|}
\hline \multicolumn{2}{|c|}{$\begin{array}{c}\text { Total Asset (in million } \\
\text { Taka) }\end{array}$} & 2006 & 2007 & 2008 & 2009 & 2010 & 2011 & $\begin{array}{c}\text { Growth } \\
\text { Rate }\end{array}$ & Average \\
\hline $\begin{array}{l}\text { 1st } \\
\text { Generation }\end{array}$ & AB Bank & 47,989 & 63,549 & 84,053 & 106,912 & 132,691 & 152,962 & $219 \%$ & 98,026 \\
\hline \multirow{2}{*}{$\begin{array}{l}\text { nd } \\
\text { Generation }\end{array}$} & Bank Asia & 30,478 & 38,436 & 53,371 & 68,663 & 105,198 & 117,729 & $286 \%$ & 68,979 \\
\cline { 2 - 11 } & $\begin{array}{l}\text { Dhaka } \\
\text { Bank }\end{array}$ & 47,593 & 57,443 & 71,136 & 77,767 & 90,140 & 105,037 & $121 \%$ & 74,853 \\
\hline \multirow{3}{*}{$\begin{array}{l}\text { 3rd } \\
\text { Generation }\end{array}$} & $\begin{array}{l}\text { Southeast } \\
\text { Bank }\end{array}$ & 6,265 & 64,370 & 81,181 & 112,676 & 131,943 & 518,078 & $8169 \%$ & 152,419, \\
\cline { 2 - 11 } & $\begin{array}{l}\text { BRAC } \\
\text { Bank }\end{array}$ & 30,011 & 46,382 & 72,441 & 94,581 & 117,297 & 133,201 & $344 \%$ & 82,319 \\
\hline
\end{tabular}

Based on average asset, again Southeast bank tops the chart with an average asset of BDT 152,419 million, whereas Dhaka Bank had the lowest average asset of BDT 74,853 million from the year 2006-2011.

Table 2 shows total deposit of all selected commercial banks in Bangladesh with its growth rate and average. The table reveals that of all the banks under study, BRAC Bank was able to achieve the highest growth in total deposit. Bank Asia holds the second position with regard to deposit growth. Dhaka bank bottoms the chart with a deposit growth rate of $105 \%$.

Table 2: Total Deposits of the Selected Bangladeshi Commercial Banks (2006-2011)

\begin{tabular}{|l|l|c|c|c|c|c|c|c|c|}
\hline \multicolumn{2}{|c|}{$\begin{array}{c}\text { Total Deposit (in million } \\
\text { Taka) }\end{array}$} & 2006 & 2007 & 2008 & 2009 & 2010 & 2011 & $\begin{array}{c}\text { Growth } \\
\text { Rate }\end{array}$ & Average \\
\hline $\begin{array}{l}\text { 1st } \\
\text { Generation }\end{array}$ & AB Bank & 42,076 & 53,375 & 68,560 & 83,087 & 95,701 & 116,151 & $176 \%$ & 76,492 \\
\hline \multirow{2}{*}{$\begin{array}{l}\text { nd } \\
\text { Generation }\end{array}$} & Bank Asia & 25,289 & 30,004 & 42,435 & 54,832 & 86,365 & 95,131 & $276 \%$ & 55,676 \\
\cline { 2 - 11 } & $\begin{array}{l}\text { Dhaka } \\
\text { Bank }\end{array}$ & 41,553 & 48,730 & 56,985 & 60,918 & 70,420 & 85,276 & $105 \%$ & 60,647 \\
\hline \multirow{3}{*}{$\begin{array}{l}\text { Gend } \\
\text { Genetion }\end{array}$} & $\begin{array}{l}\text { Southeast } \\
\text { Bank }\end{array}$ & 46,056 & 55,474 & 68,714 & 96,669 & 107,253 & 127,178 & $176 \%$ & 83,557 \\
\cline { 2 - 11 } & $\begin{array}{l}\text { BRAC } \\
\text { Bank }\end{array}$ & 22,888 & 36,903 & 57,582 & 74,765 & 87,136 & 102,957 & $350 \%$ & 63,705 \\
\hline
\end{tabular}

Based on average deposit for the year 2006-2011 Southeast bank tops the list with an average deposit of BDT 83,557 million. Whereas Bank Asia who had the second highest deposit growth, had the lowest average deposit of BDT 55,676 million.

Table 3 shows the total credit, the growth rate of credit and the average of total credit for the year 2006-2011. From the table it is clear that Southeast bank had the highest credit growth with a growth rate of 908\%, whereas Dhaka Bank had the lowest growth in credit. The second highest growth was achieved by AB bank.

Table 3: Total Credits of the Selected Bangladeshi Commercial Banks (2006-2011)

\begin{tabular}{|l|l|c|c|c|c|c|c|c|c|}
\hline \multicolumn{2}{|c|}{ Total Credit (in million Taka) } & 2006 & 2007 & 2008 & 2009 & 2010 & 2011 & $\begin{array}{c}\text { Growth } \\
\text { Rate }\end{array}$ & Average \\
\hline 1st Generation & AB Bank & 1,297 & 1,872 & 6,125 & 3,193 & 14,200 & 10,248 & $690 \%$ & 6,156 \\
\hline \multirow{3}{*}{ 2nd Generation } & Bank Asia & 22,255 & 28,456 & 39,974 & 50,267 & 79,504 & 82,819 & $272 \%$ & 50,546 \\
\cline { 2 - 11 } & $\begin{array}{l}\text { Dhaka } \\
\text { Bank }\end{array}$ & 34,048 & 39,971 & 49,697 & 52,909 & 63,591 & 75,983 & $123 \%$ & 52,700 \\
\hline \multirow{3}{*}{3 rd Generation } & $\begin{array}{l}\text { Southeast } \\
\text { Bank }\end{array}$ & 314 & 48,164 & 60,281 & 261 & 976 & 3,168 & $908 \%$ & 18,861 \\
\cline { 2 - 11 } & $\begin{array}{l}\text { BRAC } \\
\text { Bank }\end{array}$ & 19,557 & 32,461 & 52,676 & 64,150 & 82,461 & 90,822 & $364 \%$ & 57,021 \\
\hline
\end{tabular}


Based on average credit, BRAC Bank tops the chart with an average credit of BDT 57,021 million. AB bank had the lowest average credit of BDT 6,156 million, even after having the second highest growth in credit during the years.

According to table 4, Bank Asia gained the highest growth rate of 540\% in total owner's equity during 2006-2011. The second on the list was AB bank with a growth rate of $475 \%$. Dhaka bank had the lowest growth among the banks under study.

Table 4: Total Owner's Equity of the Selected Bangladeshi Commercial Banks (2006-2011)

\begin{tabular}{|c|c|c|c|c|c|c|c|c|c|}
\hline \multicolumn{2}{|c|}{ Total Equity (in million Taka) } & 2006 & 2007 & 2008 & 2009 & 2010 & 2011 & $\begin{array}{c}\text { Growth } \\
\text { Rate }\end{array}$ & Average \\
\hline 1st Generation & AB Bank & 2,582 & 4,511 & 6,722 & 10,086 & 13,866 & 14,852 & $475 \%$ & 8,770 \\
\hline \multirow{2}{*}{ 2nd Generation } & Bank Asia & 1,949 & 2,577 & 3,332 & 4,954 & 7,059 & 12,478 & $540 \%$ & 5,392 \\
\hline & Dhaka Bank & 2,550 & 3,125 & 3,999 & 4,965 & 6,579 & 9,293 & $264 \%$ & 5,085 \\
\hline \multirow[t]{2}{*}{ 3rd Generation } & $\begin{array}{l}\text { Southeast } \\
\text { Bank }\end{array}$ & 5,059 & 6,144 & 7,357 & 11,329 & 17,145 & 19,383 & $283 \%$ & 11,069 \\
\hline & BRAC Bank & 2,117 & 3,072 & 5,437 & 8,150 & 9,417 & 9,602 & $354 \%$ & 6,299 \\
\hline
\end{tabular}

Based on average of total owner's equity Southeast bank tops the chart with an average of BDT 11,069 million, $\mathrm{AB}$ bank holds the second position with an average of BDT 8,770 million. Even though Bank Asia ranks first in equity growth it had near about the lowest average equity during the years.

Table 5 reveals that BRAC Bank gained the highest growth in total interest income during the years under study, whereas Dhaka Bank had the lowest growth. AB bank has the second highest growth. The findings in this table reinforces that results in table 4 regarding credit growth, as interest income is the income earned on total credit.

Table 5: Total Interest Income of the Selected Bangladeshi Commercial Banks (2006-2011)

\begin{tabular}{|c|c|c|c|c|c|c|c|c|c|}
\hline \multicolumn{2}{|c|}{ Interest Income (in million Taka) } & 2006 & 2007 & 2008 & 2009 & 2010 & 2011 & $\begin{array}{c}\text { Growth } \\
\text { Rate }\end{array}$ & Average \\
\hline 1st Generation & AB Bank & 3,378 & 5,269 & 7,366 & 9,047 & 9,840 & 12,830 & $280 \%$ & 7,955 \\
\hline \multirow{2}{*}{ 2nd Generation } & Bank Asia & 2,842 & 3,662 & 4,973 & 6,247 & 8,381 & 10,619 & $274 \%$ & 6,121 \\
\hline & Dhaka Bank & 4,341 & 5,635 & 7,171 & 7,466 & 7,404 & 9,945 & $129 \%$ & 6,994 \\
\hline \multirow[t]{2}{*}{ 3rd Generation } & $\begin{array}{l}\text { Southeast } \\
\text { Bank }\end{array}$ & 5,107 & 6,408 & 7,530 & 8,962 & 10,257 & 13,874 & $172 \%$ & 8,690 \\
\hline & BRAC Bank & 2,077 & 3,546 & 6,036 & 7,264 & 9,539 & 10,795 & $420 \%$ & 6,543 \\
\hline
\end{tabular}

Based on average interest income Southeast bank tops the list with an average of BDT 8,690 million, followed by AB Bank ranking second with an average of BDT 7,955 million. Bank Asia had the lowest average interest income among the banks under study.

\subsection{Profitability Dimension}

The return on equity ratio reflects the bank management's ability to generate net profits from using the owner's equity as one of the source of finance. Table 6 reveals that Southeast Bank was able to generate the highest ROE during the years with an average of $40 \%$ with $\mathrm{AB}$ bank having the second highest average ROE of $28 \%$. BRAC Bank had the lowest average ROE. The table reveals that based on average ROE, both the top ranked and the bottom ranked banks belong to the same $3^{\text {rd }}$ generation of banks.

Table 6: Return on Equity Ratios of Selected Bangladeshi Banks (2006-2011)

\begin{tabular}{|l|l|c|c|c|c|c|c|c|}
\hline \multicolumn{2}{|c|}{ ROE } & 2006 & 2007 & 2008 & 2009 & 2010 & 2011 & Average \\
\hline 1st Generation & AB Bank & $21 \%$ & $42 \%$ & $34 \%$ & $33 \%$ & $27 \%$ & $9 \%$ & $28 \%$ \\
\hline \multirow{2}{*}{ 2nd Generation } & Bank Asia & $24.40 \%$ & $25.60 \%$ & $20.60 \%$ & $26.79 \%$ & $27.33 \%$ & $12.95 \%$ & $23 \%$ \\
\cline { 2 - 9 } & Dhaka Bank & $22.76 \%$ & $22.52 \%$ & $20.97 \%$ & $19.32 \%$ & $25.52 \%$ & $23.30 \%$ & $22 \%$ \\
\hline \multirow{2}{*}{3 rd Generation } & Southeast Bank & $40.77 \%$ & $47.46 \%$ & $40.95 \%$ & $40.73 \%$ & $39.40 \%$ & $29.99 \%$ & $40 \%$ \\
\cline { 2 - 9 } & BRAC Bank & $15.79 \%$ & $20.13 \%$ & $17.90 \%$ & $15.99 \%$ & $22.01 \%$ & $18.87 \%$ & $18 \%$ \\
\hline
\end{tabular}

Net Profit Margit reflects a bank's financial position and efficiency. Table 7 indicates that Southeast Bank had the highest NPM (48\%) compared to other banks under study, followed by AB bank in the second position with an average NPM of 28\%. Both Bank Asia and BRAC Bank had the lowest average NPM. 
The Performance Analysis of Private Conventional Banks: A Case Study of Bangladesh

Table 7: Net Profit Margin Ratios of Selected Bangladeshi Banks (2006-2011)

\begin{tabular}{|l|l|c|c|c|c|c|c|c|}
\hline & & 2006 & 2007 & 2008 & 2009 & 2010 & 2011 & Average \\
\hline 1st Generation & AB Bank & $16 \%$ & $36 \%$ & $31 \%$ & $37 \%$ & $38 \%$ & $10 \%$ & $28 \%$ \\
\hline \multirow{2}{*}{ 2nd Generation } & Bank Asia & $16.74 \%$ & $18.01 \%$ & $13.81 \%$ & $21.24 \%$ & $23.02 \%$ & $15.22 \%$ & $18 \%$ \\
\cline { 2 - 9 } & Dhaka Bank & $28.17 \%$ & $22.20 \%$ & $21.58 \%$ & $23.48 \%$ & $30.22 \%$ & $34.77 \%$ & $27 \%$ \\
\hline \multirow{2}{*}{3 rd Generation } & Southeast Bank & $40.38 \%$ & $45.50 \%$ & $40.00 \%$ & $51.49 \%$ & $65.86 \%$ & $41.90 \%$ & $48 \%$ \\
\cline { 2 - 9 } & BRAC Bank & $16.09 \%$ & $17.44 \%$ & $16.13 \%$ & $17.95 \%$ & $21.73 \%$ & $16.79 \%$ & $18 \%$ \\
\hline
\end{tabular}

\subsection{Liquidity Dimension}

Cash ratio measures the extent to which a bank can quickly liquidate assets and cover short-term liabilities, and therefore is of interest to short-term depositors. Table 8 reflects that Southeast bank has the highest average cash ratio (0.16) followed by AB Bank (0.12) in the second position. Dhaka Bank bottoms the list with an average cash ratio of 0.01 over the years under study.

Table 8: Cash Ratios of Selected Bangladeshi Banks (2006-2011)

\begin{tabular}{|l|l|c|c|c|c|c|c|c|}
\hline \multicolumn{2}{|c|}{ Cash Ratio } & 2006 & 2007 & 2008 & 2009 & 2010 & 2011 & Average \\
\hline 1st Generation & AB Bank & 0.11 & 0.12 & 0.09 & 0.11 & 0.13 & 0.15 & 0.12 \\
\hline \multirow{2}{*}{ 2nd Generation } & Bank Asia & 0.07 & 0.07 & 0.07 & 0.07 & 0.07 & 0.07 & 0.07 \\
\cline { 2 - 10 } & Dhaka Bank & 0.01 & 0.01 & 0.01 & 0.01 & 0.01 & 0.01 & 0.01 \\
\hline \multirow{2}{*}{ 3rd Generation } & Southeast Bank & 0.06 & 0.06 & 0.18 & 0.22 & 0.18 & 0.23 & 0.16 \\
\cline { 2 - 9 } & BRAC Bank & 0.02 & 0.01 & 0.02 & 0.02 & 0.04 & 0.04 & 0.02 \\
\hline
\end{tabular}

Loans to deposit ratio indicates a banks liquidity position. A low ratio of loans to deposits indicates excess liquidity, and potentially low profits, compared to other banks. A high loan-to-deposit ratio presents the risk that some loans may have to be sold at a loss to meet depositors' claims. Table 9 reveals that Southeast bank has the strongest liquidity position based on average of loans to deposit ratios with other banks having an average loan to deposit ratios varying within a narrow range.

Table 9: Loans to Deposit Ratios of Selected Bangladeshi Banks (2006-2011)

\begin{tabular}{|l|l|c|c|c|c|c|c|c|}
\hline \multicolumn{2}{|c|}{ Loans to Total Deposit } & 2006 & 2007 & 2008 & 2009 & 2010 & 2011 & Average \\
\hline $\begin{array}{l}\text { 1st } \\
\text { Generation }\end{array}$ & AB Bank & 0.74 & 0.77 & 0.83 & 0.85 & 0.92 & 0.81 & 0.82 \\
\hline $\begin{array}{l}\text { 2nd } \\
\text { Generation }\end{array}$ & Bank Asia & 0.88 & 0.95 & 0.94 & 0.92 & 0.92 & 0.87 & 0.91 \\
\cline { 2 - 9 } & Dhaka Bank & 0.82 & 0.82 & 0.87 & 0.87 & 0.90 & 0.89 & 0.86 \\
\hline \multirow{2}{*}{$\begin{array}{l}\text { 3rd } \\
\text { Generation }\end{array}$} & $\begin{array}{l}\text { Southeast } \\
\text { Bank }\end{array}$ & 0.01 & 0.87 & 0.88 & 0.00 & 0.01 & 0.02 & 0.30 \\
\cline { 2 - 10 } & BRAC Bank & 0.85 & 0.88 & 0.91 & 0.86 & 0.95 & 0.88 & 0.89 \\
\hline
\end{tabular}

\subsection{Credit Risk Dimension}

Equity to total asset ratio indicates a bank's ability to absorb credit risk in case of default by the borrowers. A high equity to total asset ratio indicates a higher ability of a bank to absorb credit default. Table 10 shows that Southeast bank had the highest average ratio (0.09) with Dhaka bank (0.06) in the bottom during the years under study.

Table 10: Equity to Total Asset Ratios of Selected Bangladeshi Banks (2006-2011)

\begin{tabular}{|l|l|c|c|c|c|c|c|c|}
\hline \multicolumn{2}{|c|}{ Equity to Total Asset } & 2006 & 2007 & 2008 & 2009 & 2010 & 2011 & Average \\
\hline 1st Generation & AB Bank & 0.05 & 0.07 & 0.08 & 0.09 & 0.10 & 0.10 & 0.08 \\
\hline \multirow{2}{*}{$\begin{array}{l}\text { 2nd } \\
\text { Generation }\end{array}$} & Bank Asia & 0.064 & 0.067 & 0.062 & 0.072 & 0.067 & 0.106 & 0.07 \\
\cline { 2 - 10 } & Dhaka Bank & 0.054 & 0.054 & 0.056 & 0.064 & 0.073 & 0.088 & 0.06 \\
\hline \multirow{2}{*}{$\begin{array}{l}\text { Gend } \\
\text { Genation }\end{array}$} & $\begin{array}{l}\text { Southeast } \\
\text { Bank }\end{array}$ & 0.09 & 0.10 & 0.09 & 0.10 & 0.13 & 0.04 & 0.09 \\
\cline { 2 - 10 } & BRAC Bank & 0.07 & 0.07 & 0.08 & 0.09 & 0.08 & 0.07 & 0.08 \\
\hline
\end{tabular}

\subsection{Efficiency Dimension}

The fixed-asset turnover ratio measures bank's ability to generate net sales from fixed-asset investments. A higher fixed-asset turnover ratio shows that the bank has been more effective in using the investment in fixed assets to generate revenues. Table 11 reveals that Dhaka bank has the highest average ratio compared to other banks under study with Bank Asia in the second position. Southeast bank has the lowest average ratio during the year 2006-2011. 
The Performance Analysis of Private Conventional Banks: A Case Study of Bangladesh

Table 11: Fixed Asset Turnover Ratios of Selected Bangladeshi Banks (2006-2011)

\begin{tabular}{|l|l|c|c|c|c|c|c|c|}
\hline \multicolumn{2}{|c|}{ Fixed Asset Turnover } & 2006 & 2007 & 2008 & 2009 & 2010 & 2011 & Average \\
\hline 1st Generation & AB Bank & 2.94 & 2.21 & 3.01 & 3.71 & 2.51 & 3.33 & 2.95 \\
\hline \multirow{2}{*}{$\begin{array}{l}\text { Gnd } \\
\text { Generation }\end{array}$} & Bank Asia & 5.88 & 7.35 & 7.72 & 6.13 & 4.56 & 2.32 & 5.66 \\
\cline { 2 - 9 } $\begin{array}{l}\text { 3rd } \\
\text { Generation }\end{array}$ & Dhaka Bank & 9.48 & 10.88 & 10.05 & 9.62 & 5.68 & 3.62 & 8.22 \\
\cline { 2 - 9 } & Southeast Bank & 2.09 & 2.24 & 1.50 & 1.36 & 1.90 & 1.10 & 1.70 \\
\hline
\end{tabular}

Net Asset turnover ratio indicates a bank's efficiency in utilizing its asset. Table 12 indicates that Bank Asia had the highest average ratio compared to other banks under study, whereas Dhaka Bank had the lowest average ratio indicating the lowest efficiency in utilizing its asset to generate revenue during the years under study.

Table 12: Net Asset Turnover Ratios of Selected Bangladeshi Banks (2006-2011)

\begin{tabular}{|l|l|c|c|c|c|c|c|c|}
\hline \multicolumn{2}{|c|}{ Net Asset Turnover } & 2006 & 2007 & 2008 & 2009 & 2010 & 2011 & Average \\
\hline 1st Generation & AB Bank & 0.07 & 0.08 & 0.09 & 0.08 & 0.07 & 0.08 & 0.08 \\
\hline \multirow{2}{*}{$\begin{array}{l}\text { 2nd } \\
\text { Generation }\end{array}$} & Bank Asia & 1.46 & 1.42 & 1.49 & 1.26 & 1.19 & 0.85 & 1.28 \\
\cline { 2 - 10 } & Dhaka Bank & 0.04 & 0.06 & 0.05 & 0.05 & 0.06 & 0.06 & 0.05 \\
\hline \multirow{2}{*}{$\begin{array}{l}\text { Grd } \\
\text { Generation }\end{array}$} & Southeast Bank & 0.54 & 0.62 & 0.55 & 0.52 & 0.49 & 0.42 & 0.52 \\
\cline { 2 - 9 } & BRAC Bank & 0.07 & 0.08 & 0.08 & 0.08 & 0.08 & 0.08 & 0.08 \\
\hline
\end{tabular}

Table 13 summarizes the rating of the banks based on their activities and ratios. According to Table 13, Southeast bank is ranked first based on most indicators under study except for total credit, fixed asset turnover and net asset turnover. Therefore it is very clear that Southeast bank needs to improve its efficiency in asset management.

$\mathrm{AB}$ Bank holds the second position based on profitability, liquidity, credit risk but holds fourth and third position in fixed asset turnover and net asset turnover respectively. Moreover it is ranked fifth on total credit. Therefore AB bank needs to work on utilizing both its fixed and net asset management, at the same time it should try to tap more credit by expanding its market base.

BRAC bank is ranked first based on avg. of total credit, but is ranked third in total asset, total deposit, total equity, equity to total asset ratio, fixed asset turnover ratio, ranked fourth in interest income and cash ratio, loans to total deposit ratio, net asset turnover ratio and ranked fifth in ROE and NPM. Therefore BRAC bank needs to put more emphasis on profitability, liquidity, credit risk and efficiency respectively. And maintain its total credit at the present level.

Table 13: Summary of Bank's ranking based on activities and Ratios

\begin{tabular}{|c|c|c|c|c|c|}
\hline Banks/Indicators & $\begin{array}{c}\text { Southeast } \\
\left(3^{\text {rd }} \text { Generation }\right.\end{array}$ & $\begin{array}{c}\text { AB Bank } \\
\left(1^{\text {st }} \text { Generation }\right)\end{array}$ & $\begin{array}{c}\text { BRAC } \\
\left(3^{\text {rd }} \text { Generation }\right)\end{array}$ & $\begin{array}{c}\text { Bank Asia } \\
\left(2^{\text {nd }} \text { Generation }\right)\end{array}$ & $\begin{array}{c}\text { Dhaka } \\
\left(2^{\text {nd }} \text { Generation }\right)\end{array}$ \\
\hline Avg. of Total Asset & 1 & 2 & 3 & 5 & 4 \\
\hline Avg. of Total Deposit & 1 & 2 & 3 & 5 & 4 \\
\hline Avg. of Total Credit & 4 & 5 & 1 & 3 & 2 \\
\hline Avg. of Total Equity & 1 & 2 & 3 & 4 & 5 \\
\hline $\begin{array}{l}\text { Avg. of Interest } \\
\text { Income }\end{array}$ & 1 & 2 & 4 & 5 & 3 \\
\hline Return on Equity & 1 & 2 & 5 & 3 & 4 \\
\hline Net Profit Margin & 1 & 2 & 5 & 4 & 3 \\
\hline Cash Ratio & 1 & 2 & 4 & 3 & 5 \\
\hline $\begin{array}{l}\text { Loans to Total } \\
\text { Deposit }\end{array}$ & 1 & 2 & 4 & 5 & 3 \\
\hline Equity to Total Asset & 1 & 2 & 3 & 4 & 5 \\
\hline Fixed Asset Turnover & 5 & 4 & 3 & 2 & 1 \\
\hline Net Asset Turnover & 2 & 3 & 4 & 1 & 5 \\
\hline
\end{tabular}

Bank Asia is ranked first based on net asset turnover ratio, second on fixed asset turnover ratio, third on total credit, ROE and cash ratio, fourth on total equity, NPM, equity to total asset ratio and ranked fifth on total asset, total deposit, interest income, loans to total deposit ratio. So it should try to improve its overall performance in most of the indicators under study except for asset utilization.

Dhaka bank is ranked first on the basis of fixed asset turnover, ranked second on total credit, ranked third on interest income, NPM, loans to deposit ratio, ranked fourth on total asset to deposit, ROE, and ranked fifth on total equity, cash ratio, equity to total asset ratio and net asset turnover ratio. Therefore strong effort 
must be given by the bank's management to improve the overall performance of the bank based on all the parameters under study.

From Table 13 it is clear that there exists no relationship between banks years of operation and its performance. Southeast bank being a third generation bank tops the list whereas BRAC bank being in the same generation was not able to perform in the same pace. Moreover AB Bank being a first generation bank was not able to outperform Southeast bank. The study finding has been reinforced by the fact that there is no co-relation between the performance of Bank Asia and Dhaka bank, both being a second generation bank.

\section{Conclusion}

The importance of this study stems from the relative size and importance of banking sector in Bangladesh, comprising of $61 \%$ of GDP. The study is considered to make huge contribution not only in the field of academic research but also in helping managers to improve bank's performance.

This study will help managers to pay more attention to the aspects where these banks are lagging behind which may result in improving both their financial performance and ranking. This study will also pave the way of efficient and effective strategic decision making by the managers. From the academic point of view this research will provide a new perspective in evaluating the financial performance of Bangladeshi commercial banks that belongs to different generations. The findings of this study will enrich the present literature and it will help researchers in their future endeavor.

The result of the study reveals that Southeast bank, a third generation bank in Bangladesh is ranked first based on most of the indicators except for total credit, fixed asset turnover and net asset turnover. AB Bank, a first generation bank in Bangladesh, holds the second position based on profitability, liquidity, credit risk but holds fourth and third position in fixed asset turnover and net asset turnover respectively. Moreover it is ranked fifth on total credit. BRAC bank, again a third generation bank in Bangladesh, is ranked first based on avg. of total credit, but is ranked third in total asset, total deposit, total equity, equity to total asset ratio, fixed asset turnover ratio, ranked fourth in interest income and cash ratio, loans to total deposit ratio, net asset turnover ratio and ranked fifth in ROE and NPM. Bank Asia, a second generation bank in Bangladesh, is ranked first based on net asset turnover ratio, second on fixed asset turnover ratio, third on total credit, ROE and cash ratio, fourth on total equity, NPM, equity to total asset ratio and ranked fifth on total asset, total deposit, interest income, loans to total deposit ratio. Dhaka bank, a second generation bank in Bangladesh, is ranked first on the basis of fixed asset turnover, ranked second on total credit, ranked third on interest income, NPM, loans to deposit ratio, ranked fourth on total asset to deposit, ROE, and ranked fifth on total equity, cash ratio, equity to total asset ratio and net asset turnover ratio.

The study findings reveal that there is no specific relationship between the generation of banks and its performance. The performances of banks are dependent more on the management's ability in formulating strategic plans and the efficient implementation of their strategies. The study had its limitation of having a small sample size, but it will definitely help future researches to work more in depth on the topic.

\section{Reference}

[1] Ahmed A. Almazari, Financial Performance Evaluation of Some Selected Jordanian Commercial Banks, International Research Journal of Finance and Economics 68, 2011, ISSN 1450-2887.

[2] Ashraf M. and Rehman Z.,The Performance Analysis of Islamic and Conventional Banks: The Pakistan's Perspective, Journal of Money, Investment and Banking 22, 2011,ISSN 1450-288X.

[3] Rehman K. and Saba I, Gauging The Financial Performance of Banking Sector Using CAMEL Model: Comparison of Conventional, Mixed and Pure Islamic Banks in Pakistan, International Research Journal of Finance and Economics 82, 2012, ISSN 1450-2887.

[4] Nimalathasan, A Comparative Study of Financial Performance of Banking Sector in Bangladesh - An Application of CAMEL Rating System, Annals of University of Bucharest, Economic and Administrative Series. Nr. 2, 2008, pp 141-152.

[5] Chowdhury, A, Politics, Society and Financial Sector Reform in Bangladesh, International Journal of Social Economics, 29(12), 2002, pp 963-988.

[6] Siddique, S. H., and Islam, A. F. M. M. Banking Sector in Bangladesh: Its Contribution and Performance, Journal of Business Research, Jahangirnagar University, Vol. 3, 2001.

[7] Libby, R, Accounting Ratios and Prediction of Failure: Some Behavioral Evidence, Journal of Accounting Research Spring, 1975, pp 150-161.

[8] O'Cornor and Malvin C., On the Usefulness of Financial Ratios to Investors in Common Stock, The Accounting Review, April, 1973, pp 339-83.

[9] Thomas A. Shimerda and Kung H. Chen, An Empirical Analysis of Useful Financial Ratios, Blackwell Publishers, Vol. 10, 1981, pp 51-60.

[10] Samad, A., Hasan, M. K., The Performance of Malayasian Islamic Bank During 1984-1997: An Explanatory Study, International Journal of Islamic Financial Service, 1 (3), 1999.

[11] Sabi, M., Comparative Analysis of Foreign and Domestic Bank Operations in Hungary, Journal of Comparative Economics 22, no. 2, 1996, pp 1979-88.

[12] Ahmed and Hasan, Regulations and Performance of Islamic Banking System in Bangladesh, Thunderbird International Business Review, Vol. 49(2), 2007, pp 251-277. 